\title{
Giant stentolith: complication of a forgotten biliary
}

\section{stent}

A 50-years-old woman underwent open cholecystectomy after endoscopic retrograde cholangiography, clearance of the common bile duct (CBD), and plastic stent placement. She had undergone sphincterotomy for cholangitis 4 years previously, but did not report for follow-up as she apparently remained asymptomatic. She now presented with epigastric pain and jaundice, which she had had for 1 month, with no fever. Laboratory tests were normal except raised levels of serum bilirubin $(3.8 \mathrm{mg} / \mathrm{dL}$, normal range $<1.2 \mathrm{mg} / \mathrm{dL})$, serum glutamic oxaloacetic transaminase (SGOT) (61 IU/L, normal range < $43 \mathrm{IU} / \mathrm{L})$, serum glutamic pyruvic transaminase (SGPT) (58 IU/L, normal range < $43 \mathrm{IU} / \mathrm{L})$, and serum alkaline phosphatase (388 IU/L, normal range $<306 \mathrm{IU} / \mathrm{L}$ ). Abdominal ultrasound revealed a large $(18 \mathrm{~mm} \times 15 \mathrm{~mm})$ stone along with a stent within the dilated $\mathrm{CBD}$. Endoscopy confirmed the presence of stent. Endoscopic CBD clearance, however, was not attempted in view of the large size of the stone. Open CBD exploration revealed a large cast of stone $(\sim 8 \mathrm{~cm} \times 2 \mathrm{~cm})$ encasing the intrabiliary part of the stent (๑ Fig. 1), which was removed with difficulty. After choledochoscopy to ensure complete CBD clearance, choledochoduodenostomy was carried out with an uneventful postoperative course.

A forgotten stent in the CBD may remain in situ for years without any complication [1] or may undergo migration, with its attendant problems such as fistulization [2]. Rarely, a retained stent may act as a nidus for stone formation around it, which is known as "stentolith" [3]. As the stent may get impacted within the stone, an endoscopic procedure may not be successful in such cases, specially with a large stentolith, mandating surgical removal. Relief of jaundice by the stent might be the cause why some patients forget or avoid getting such stents removed or replaced despite advice to the contrary. In benign cases, close follow-up with timely removal or regular replacement of such stents is important to prevent complications.

Endoscopy_UCTN_Code_CPL_1AK_2AD

Competing interests: None

\section{Gupta, A. Chandra, M. Noushif, S. K. Singh}

Department of Surgical Gastroenterology, King George Medical University, Lucknow, Uttar Pradesh, India

\section{References}

1 Bajbouj M, Treiber M, Ludwig L et al. Forgotten biliary endoprosthesis. "Follow up" after 10 years. Endoscopy 2008; 40: E221

2 Namdar T, Raffel AM, Topp SA et al. Complications and treatment of migrated biliary endoprostheses: a review of the literature. World J Gastroenterol 2007; 13: 5397-5399

3 Bansal VK, Misra MC, Bhowate $P$ et al. Laparoscopic management of common bile duct "Stentolith". Trop Gastroenterol 2009; 30: $95-96$

\section{Bibliography}

Dol http://dx.doi.org/

$10.1055 / \mathrm{s}-0032-1326367$

Endoscopy 2013; 45: E126

(C) Georg Thieme Verlag KG

Stuttgart · New York

ISSN 0013-726X

\section{Corresponding author}

\section{Dr A. Chandra}

Department of Surgical Gastroenterology

King George Medical University

Lucknow, UP

India

Fax: +91522 2256116

abhijitchandra@hotmail.com

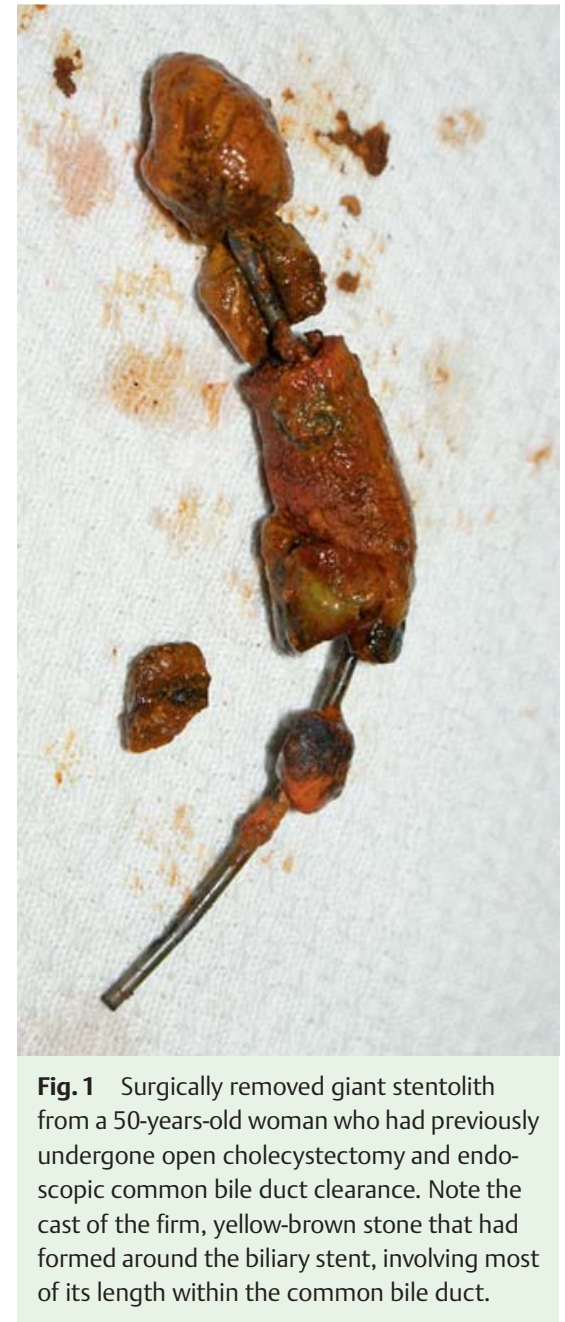

